\title{
UNDERSTANDING TERRORISM AS FEAR-BASED OPPRESSION
}

\author{
Sageman M. Misunderstanding Terrorism. - \\ Philadelphia: University of Pennsylvania Press, \\ 2016. 224 p.
}

\section{DOI: $10.20542 / 2307-1494-2018-2-150-152$}

Marc Sageman, M.D., Ph.D., is a forensic psychiatrist and a lead U.S. academic expert on terrorism. He is also a former CIA Operations Officer (formally a Foreign Service officer) who had been based in Islamabad (in 1987-1989) where he had worked with the Afghan mujahedin. In the recent decades, he has instructed different branches of the U.S. government on counterterrorism.

Sageman's book "Misunderstanding Terrorism" speaks to his most recent push to slice through the perplexity and stagnation (that, according to him, plagues much of the current research on terrorism) "by bringing realistic numbers into the assessment of the threat facing the West" (p. 22). He argues that the primary issue in terrorism studies is making a distinction between mastery and information: "Academics understand everything but know nothing, while government analysts know everything but understand nothing" (p. 21). This detachment results in a severely segmented field of expertise, powerless against "popular hysteria" (p. 21) and supporting frequently poorly-judged open discourse. Sageman aims at, and generally accomplishes, a helpful restorative. For some, including multiple policy analysts and self-proclaimed experts, his book will hardly be a sweet pill, yet it definitely enhances the general state of our comprehension of what the writer calls "the global neojihadi threat to the West" (p. 24).

Sageman successfully bridges the gap between expository aptitude and solid psychological warfare information that he fully acknowledges. His educational and scholarly background in political and human sciences and his expertise as a legal specialist, combined with his deep-rooted "obsession with political violence" (p. 1) led to a sequence of professional occupations that allowed him to compose "a database on all global neojihadi incidents in the West since 9/11" (p. 28) and through September 10, 2011. This dataset is based on his own field inquiries, interviews, watchful audit of court archives, records, and press reports. It incorporates "66 global neojihadi plots or attacks in the West during the post-9/11 decade [which] involved 220 individuals" (p. 29). The book also includes a table placing the cases alongside key points of interest. Examining his data patterns, Sageman confirms some of his own earlier findings that contradicted dominant perceptions in works on psychological warfare and terrorism. For instance, his data-based conclusions suggest that, in contrast to common wisdom, the peril of terrorism as psychological militant assault was not on the rise by the end of the first post9/11 decade and that al-Qaeda attacks specifically "were not as serious a threat" (p. 42) as they had been in the early years after $9 / 11$. Sageman argues that the vast majority of "global neojihadi plots or attacks in the West came from homegrown groups or individuals who had no significant connection to any foreign terrorist organization" (p. 46). He contends that these discoveries emphatically bolster two claims made in his prior works: first, that, by 2011, al-Qaeda was "on the run" as opposed to "moving" and,

Рабия Раджо (Афганистан) - стажер Института общественных наук Российской академии народного хозяйства и государственной службы (РАНХиГС). 
second, that the emerging global neojihadi threat was "leaderless" rather than "leaderled" (p. 51).

Having reviewed the nature and extent of the global threat posed by neojihadi fearbased oppression toward the West, and having demonstrated the inefficiency of the West's endeavor to control it, Sageman moves to explore what he sees as the main driver of this threat. Following a section devoted to flawed or insufficient explanations, he at last suggests an explanatory framework that he considers particularly persuading one that puts "social identity at the center of the process of turning politically violent" (p. 112). Basically, he contends that fear-mongers start by unequivocally relating to "in-gatherings" which they see as debilitated by antagonistic "out-groups" (p. 113). Obviously, this much could be said of practically anybody, and as Sageman's own data shows, it is hardly a common individual who resorts to political violence, especially in the West. One thing that indicates the person's psychological evolution in militant direction is a "politicized social identity" (p. 117) engaged in an "escalating conflict with an out-group (often the state)" (p. 117). Persuasive communications both between the in-gathering and out-gathering, and inside the in-group itself, lead individuals further down the path of radicalization - all the way towards "mobilization" (p. 108). Sometimes, dissatisfaction with peaceful forms of political dissent prompts the choice of a "military social identity" which then "leads a few to turn to violence in defense of their imagined community" (p. 117), particularly where they see the latter under vital threat of assault or survival, metaphorically or truly. Sageman notes that even recluses who commit fear-based oppressor acts do this on the grounds that they envision themselves to represent a bigger social class (p. 114). In sum, when perpetrators engage in political violence, they do so "not for personal motives, but for group motives" (p. 115).

Clearly, much in this book challenges current antiterrorism strategies in the West, offers some master counsel and normal demeanors, and is very persuading. In particular, it stimulates thought by anyone concerned about the neojihadi threat to the West. Of special significance is the database of neojihadi plots against the West parts of which Sageman displays and uses in his investigation, providing a series of cases, suspects, dates, national contexts etc. While this is neither the main, nor the largest database of plots covering the same period, Sageman lays out and defends his criteria for consideration or exclusion of cases in detail (barring, for instance, FBI sting activities that would not have happened without a degree of government involvement). The quality and scope of his sources merge to create a really helpful and informative collection of data. The only regrettable thing is that the more complete or even full version of the database has not been made accessible on the web, so that experts from different countries and parts of the world can examine its elements in greater detail and make their own findings and conclusions. Also, more cases and deliberations of cases contained in the database would have benefitted the author's long discussion of ingatherings and out-bunches in part 4 - even as he refers the reader to his next book "The Turn to Political Violence" where some of this work is to be done (pp. 149, 208).

Now and again, however, one also gets the feeling that something critical is missing in Sageman's investigation. His book focuses so much on using quantitative data to make insights about contemporary neojihadi peril and the adequacy or inadequacy of counterterrorism measures that this does not leave time and space for the ethical dimension and approach to both issues. In favor of the fear-based oppressors, Sageman appears to accept the view that "one man's terrorist is another man's freedom fighter" (p. 89), and suggests to "transcend the prejudices built into the terminology" (p. 91). Consequently, he defines terrorism in an extremely broad way as "public categorization of political violence by non-state actors during domestic peacetime" 
(p. 91), but ignores the fact that this very loose definition tries to put together a wide range of substantively unique types of activity. To start with, some of those actors who formally fit this definition may generally try to avoid killing, especially on the mass scale, and mainly use violence against police, armed forces or other security forces who may themselves engage in repressive violence and have civilian blood on their hands. There is also an issue of a degree of public danger and non-state actors' readiness to resort to violence - a distinction which some attempt to catch by differentiating between opportunistic actors and intentional fear-mongers. The key point here is that what makes somebody a fear-based oppressor (i. e. a terrorist) is not the level of public endorsement of, or objection to, political action s/he confers (as suggested by Sageman), but how the fear-base oppression is generated - above all, with the fact that it is intentionally directed against ordinary citizens (civilians). This qualification is absolutely essential as it points at something which is unpardonable in ethical terms under any conditions - in contrast, for instance, to "car accidents" (p. 58) that Sageman tries to compare acts of fear-based oppression with. For this ethical reason, such acts may warrant a more robust and harsher state response, including some restrictions that limit certain civil freedoms. For the same reason, it is also fully justified for the citizens to require and request the state to provide security from this kind of public threat. Throughout part 3, Sageman rejects the misconceptions of fear-mongering (terrorism) on the part of "lay public" (p. 92), "lay people" (p. 93), and "lay experts" (p. 100), but when it comes to the ethical dimension of the problem, it seems that ordinary citizens and the general public understand and know about it something that even some prominent researchers don't.

This does not diminish the solid positive research input provided by Sageman's book, especially his effort to bring more solid data and thorough investigation to a public discussion that he sees as excessively dependent on speculative analysis and theory. It is, however, worth to keep in mind that instrumentalist explanations and recommendations emphasizing utility and functionality, no matter how important they may be, are not the only relevant contemplations in framing a feasible counterterrorism response.

\section{ENDNOTES}

\footnotetext{
${ }^{1}$ Sageman M. Turning to Political Violence: The Emergence of Terrorism. - Philadelphia: University of Pennsylvania Press, 2017.
} 